\title{
SISTEM PENDUKUNG KEPUTUSAN PEMILIHAN LOKASI USAHA JASA UMKM MENERAPKAN ANALYTICAL HIERARCHY PROCESS -WEIGHTED PRODUCT METHOD
}

\author{
Diana ${ }^{1}$, Suzy Oktavia Kunang ${ }^{2}$, Iin Seprina ${ }^{3}$ \\ Dosen Universitas Bina Darma ${ }^{1,2,3}$ \\ Jalan Jenderal Ahmad Yani No.3 Palembang \\ Sur-el : diana@binadarma.ac.id ${ }^{1}$, suzi_oktavia@binadarma.ac.id ${ }^{2}$, \\ iin_seprina@binadarma.ac.id ${ }^{3}$
}

\begin{abstract}
This study produces a decision support system for selecting the location of the MSME service business in Alang-Alang Lebar Palembang. There are 2 methods used in this application, namely the Analytical Hierarchy Process (AHP) and the Weighted Product Method (WPM). AHP is used to determine the weight of the criteria and WPM is used to rank the location of the MSME service business. The criteria used in this SPK are rental fees (K1), renovation needs (K2), availability of clean water (K3), availability of electricity supply $(K 4)$, presence of asphalt roads $(K 5)$, parking space (K6), population density (K7), the presence of competitors $(K 8)$ and proximity to suppliers (K9). The AHP calculation results show that the rental fee has the highest weight, namely 0.35, which means that the level of importance of the rental fee is 35\%. The WPM calculation results show that the location of the 8th MSME service business is the recommended location.
\end{abstract}

Keywords: Desicion Support System, Service Business, UMKM, Analytical Hierarchy Process, Weighted Product Method

\begin{abstract}
Abstrak: Penelitian ini menghasilkan sebuah sistem pendukung keputusan untuk memilih lokasi usaha jasa UMKM di Kecamatan Alang-Alang Lebar Palembang. Ada 2 buah metode yang digunakan pada aplikasi ini, yaitu Analytical Hierarchy Process (AHP) dan Weighted Product Method (WPM). AHP digunakan untuk menentukan bobot kriteria dan WPM digunakan untuk melakukan perangkingan lokasi usaha jasa UMKM. Kriteria yang digunakan pada SPK ini adalah biaya sewa (K1), keperluan renovasi $(K 2)$, ketersediaan air bersih (K3), ketersediaan pasokan listrik (K4), keberadaan jalan beraspal (K5), lahan parkir (K6), kepadatan penduduk (K7), adanya pesaing (K8) dan kedekatan dengan pemasok (K9). Hasil perhitungan AHP memberikan hasil bahwa biaya sewa memiliki bobot yang tertinggi yakni 0,35 yang artinya tingkat kepentingan biaya sewa adalah 35\%. Hasil perhitungan WPM memberikan hasil bahwa lokasi usaha jasa UMKM ke 8 adalah lokasi yang direkomendasikan.
\end{abstract}

Kata kunci: Sistem Pendukung Keputusan, Usaha Jasa, UMKM, Analytical Hierarchy Process, Weighted Product Method

\section{PENDAHULUAN}

Memilih lokasi usaha akan menentukan tingkat keberhasilan usaha dimasa yang akan datang. [1] Faktor lokasi, tenaga kerja, akses, fasilitas, pasar, energi, persaingan dan peraturan pemerintah menjadi pertimbangan dalam memilih lokasi usaha jasa. [2] menuliskan bahwa pemilihan lokasi guna mencapai kesuksesan usahan dijelaskan dengan 3 variabel penting, yaitu : dekat dengan infrastruktur, kondisi lingkungan serta biaya lokasi. Biaya lokasi memiliki pengaruh yang paling besar dalam menentukan kesuksesan usaha, yakni sebesar 46\%, sedangkan dengan dengan infrastruktur dan kondisi lingkungan masing- 
masing memberi kontribusi sebesar $24 \%$ dan $25 \%$. Terdapat banyak kriteria dalam memilih lokasi usaha jasa UMKM, permasalahannya adalah pelaku bisnis memiliki batas atau kendala, terutama kendala modal, meliputi biaya sewa dan biaya renovasi bila diperlukan. Selain itu, lokasi usaha sendiri juga memiliki kondisinya masing-masing. Lokasi usaha yang murah tapi jalan belum beraspal atau ketersediaan air bersih tidak cukup baik. Atau lokasi usaha dengan penduduk disekitar sudah ramai tapi harga sewa yang mahal. Meningkatnya nilai kriteria keuntungan akan menaikkan pula nilai kriteria biaya, sehingga terjadi kepentingan yang saling bertentangan satu sama lain. Untuk mengatasi hal ini diperlukan sistem pendukung keputusan untuk memberikan rekomendasi lokasi usaha UMKM sehingga mengoptimalkan proses pengambilan keputusan.

Sistem pendukung keputusan diperkenalkan oleh G. Anthony Gorry dan Michael S. Scott Morton. Keduanya adalah professor dari MIT menulis artikel dalam jurnal yang berjudul 'A framework for Management Information System”. Berdasarkan kerangka ini dapat didefinisikan bahwa sistem pendukung keputusan ini berkaitan erat dengan sistem informasi atau model analisis yang dirancang untuk membantu para pengambil keputusan dan para professional agar mendapatkan informasi yang akurat. Sistem ini semakin banyak diteliti dan dibahas saat ini. Pada tulisannya, [3] membangun sistem pendukung keputusan untuk memilih lokasi usaha waralaba menerapkan teorema Bayes, [4] membangun sistem pendukung keputusan untuk menentukan komoditi sayuran berdasarkan karakteristik lahan, [5] membangun sistem pendukung keputusan untuk mengontrol harga sembako. Untuk membangun sistem pendukung keputusan diperlukan managemen model yang diterapkan untuk menghasilkan rekomendasi yang baik. Pada penelian ini mengabungkan 2 buah managemen model yaitu Analytical Hierarchy Process (AHP) dan Weighted Product Method (WPM).

Kesederhanaan dan kemudahan perhitungan serta hasil rekomendasi yang akurat membuat AHP dan WPM banyak digunakan pada aplikasi sistem pendukung keputusan. Dalam penelitiannya, [6] metode AHP dapat digunakan dalam penilaian kompetensi soft skill karyawan sampai menentukan nilai prioritas karyawan tertinggi, [7] menerapkan AHP pada SPK penyaluran bantuan bagi nelayan, [8] mengabungkan AHP - Promethee untuk menentukan penerima bantuan keluarga miskin, [9] menerapkan metode WPM untuk memilih notebook, [10] menerapkan WPM pada SPK menentukan penerima bantuan sosial. Pengabungan kedua metode ini diharapkan dapat menghasilkan rekomendasi keputusan yang lebih baik.

\section{METODOLOGI PENELITIAN}

\subsection{Data Penelitian}

Data yang digunakan pada penelitian ini berupa data primer yang diperoleh melalui studi pustaka, observasi dan wawancara. Studi pustaka dilakukan dengan mempejari penelitian- 
penelitian terdahulu, guna mencari teori-teori yang berkaitan. Observasi dilakukan untuk mendapatkan data awal lokasi usaha UMKM di beberapa tempat di kawasan Kecamatan Alangalang Lebar meliputi 10 lokasi. Wawancara dilakukan kepada 10 orang pemilik data awal lokasi usaha yang disurvey.

\subsection{Prosedur Penelitian}

Ada 2 metode yang akan diterapkan pada sistem pendukung keputusan ini yaitu Analytical Hierarchy Process (AHP) dan Weighted Product Method (WPM). metode AHP akan digunakan untuk proses pembobotan kriteria, sedangkan metode WPM akan digunakan pada proses perangkingan alternatif / lokasi usaha UMKM. Langkah penelitian ini adalah :

1) Menentukan kriteria pemilihan lokasi usaha jasa UMKM dengan melakukan studi pustaka.

2) Melakukan proses pengumpulan data dengan cara observasi 10 lokasi usaha lalu melakukan wawancara kepada pemiliki lokasi usaha berkaitan dengan nilai dan tingkat kepentingan masing-masing kriteria.

3) Melakukan perhitungan untuk menentukan bobot kriteria menggunakan metode AHP

4) Melakukan perhitungan untuk menentukan perangkingan lokasi usaha UMKM menggunakan metode WPM.

\subsection{Kriteria yang Digunakan}

Kriteria yang digunakan pada sistem pendukung keputusan ini mengadopsi kriteria pemilihan lokasi usaha yang ditulis oleh [2] yakni :
1) Biaya lokasi meliputi biaya sewa tempat (K1) dan kebutuhan renovasi/penataan tempat (K2).

2) Kedekatan dengan infrastruktur meliputi ketersediaan air bersih (K3), pasokan listrik (K4), keberadaan jalan beraspal (K5), ketersediaan lahan parkir (K6)

3) Kondisi lingkungan bisnis meliputi kepadatan penduduk (K7), keberadaan pesaing (K8) dan kedekatan dengan pemasok (K9)

\subsection{Konversi Nilai Kriteria}

Nilai kriteria yang dikumpulkan dapat berupa data kualitatif sehingga harus diubah ke dalam bentuk data kuantitif guna keperluan perhitungan.

Nilai kriteria biaya sewa (K1) sudah dalam bentuk data kuantitatif sehingga tidak perlu lagi dikonversi. Nilai krteria ketersediaan air bersih (K3), pasokan listrik (K4), ketersediaan lahan parkir (K6), kepadatan penduduk (K7), keberadaan pesaing (K8), kedekatan dengan pemasok (K9) dalam bentuk data kualitatif yang bisa dibentuk dalam skala linkert (sangat banyak sekali, banyak, cukup banyak, tidak banyak dan sangat tidak banyak).

Tabel 1. Konversi Nilai Kriteria K3, K4, K6, K7, K8 dan K9

\begin{tabular}{cc}
\hline Nilai Kriteria & Konversi Nilai \\
\hline Sangat Banyak & 5 \\
Banyak & 4 \\
Cukup Banyak & 3 \\
Tidak Banyak & 2 \\
Sangat Tidak Banyak & 1 \\
\hline
\end{tabular}

Nilai kriteria keberadaan jalan beraspal (K5) dapat berupa beraspal dan tidak beraspal. 
Tabel 2. Konversi Nilai Kriteria K5

\begin{tabular}{cc}
\hline Nilai Kriteria & Konversi Nilai \\
\hline Beraspal & 2 \\
Tidak Beraspal & 1 \\
\hline
\end{tabular}

Nilai untuk kriteria kebutuhan renovasi/penataan tempat (K2) dapat berupa butuh renovasi dan tidak butuh renovasi. Nilai kriteria K5 kebalikan dari nilai kriteria K2, dimana pada kriteria K5 jawaban positif akan memberikan nilai lebih besar sedangkan pada kriteria K2 jawaban positif akan memberikan nilai yang lebih kecil.

Tabel 3. Konversi Nilai Kriteria K2

\begin{tabular}{cc}
\hline Nilai Kriteria & Konversi Nilai \\
\hline Butuh Renovasi & 1 \\
Tidak Butuh Renovasi & 2 \\
\hline
\end{tabular}

\subsection{Analytical Hierarchy Process}

Prinsip dasar AHP meliputi dekomposisi, perbandingan berpasangan, sintesis prioritas dan konsistensi logis. [11], Dekomposisi merupakan penyederhanaan masalah multikriteria ke dalam bentuk hirarki yang terdiri dari 3 komponen utama, yaitu tujuan, kriteria dan alternatif pilihan. Selanjutnya melakukan perbandingan berpasangan menggunakan tabel skala perbandingan Saaty.

Tabel 4. Skala Perbandingan Saaty

\begin{tabular}{|c|c|c|}
\hline $\begin{array}{c}\text { Intensitas } \\
\text { Kepentingan }\end{array}$ & Definisi & Penjelasan \\
\hline 1 & $\begin{array}{l}\text { Equal } \\
\text { importance }\end{array}$ & $\begin{array}{lr}\text { Dua } & \text { elemen } \\
\text { dengan } & \text { pengaruh } \\
\text { yang sama besar }\end{array}$ \\
\hline 3 & $\begin{array}{l}\text { Weak } \\
\text { importance of } \\
\text { one over } \\
\text { another }\end{array}$ & $\begin{array}{lr}\text { Satu } & \text { elemen } \\
\text { sedikit } & \text { lebih } \\
\text { berperan } & \\
\text { dibandingkan } & \\
\text { elemen } & \text { yang } \\
\text { lainnya } & \end{array}$ \\
\hline 5 & $\begin{array}{l}\text { Essential or } \\
\text { strong } \\
\text { importance }\end{array}$ & $\begin{array}{l}\text { Satu elemen sangat } \\
\text { berperan } \\
\text { dibandingkan } \\
\text { elemen yang } \\
\text { lainnya }\end{array}$ \\
\hline
\end{tabular}

7

Satu elemen sangat Demonstrated berperan dan importance dominan terlihat dalam praktek

\section{Extreme} importance

2,4,6,8 Nilai-nilai antara dua nilai pertimbangan-pertimbangan yang berdekatan, Nilai ini diberikan bila ada dua kompromi di antara 2 pilihan

Berbalikan Jika untuk aktivitas i mendapat satu angka dibanding dengan aktivitas $\mathrm{j}$, maka j mempunyai nilai kebalikannya dibanding dengan $i$.

Perbandingan dilakukan berdasarkan tingkat kepentingan relatif antara dua kriteria atau dua alternatif berdasarkan pada penilaian pengambil keputusan dan membentuk matrik berpasangan.

Setiap kriteria memiliki kontribusi terhadap pencapaian tujuan penyelesaian masalah dan AHP menentukan besaran kontribusi setiap kriteria. Selanjutnya konsistensi logis merupakan hal yang penting dalam AHP.

Tabel 5. Daftar IR Konsistensi

\begin{tabular}{cc}
\hline $\begin{array}{c}\text { Ukuran Matriks } \\
(\mathbf{n})\end{array}$ & $\begin{array}{c}\text { Nilai IR (Indeks } \\
\text { Random) }\end{array}$ \\
\hline 1,2 & 0.00 \\
3 & 0.58 \\
4 & 0.90 \\
5 & 1.12 \\
6 & 1.24 \\
7 & 1.32 \\
8 & 1.41 \\
9 & 1.45 \\
10 & 1.49 \\
11 & 1.51 \\
12 & 1.48 \\
13 & 1.56 \\
14 & 1.57 \\
15 & 1.59 \\
\hline
\end{tabular}

Persamaan untuk menghitung nilai konsistensi,

$C I=\frac{\lambda_{m a k s}-n}{n-1}$ 
Dan

$$
C R=\frac{C I}{I R}
$$

Keterangan :

$\mathrm{n}$ = banyaknya kriteria

$\mathrm{CI}=$ Indek Konsistensi

$\mathrm{CR}=$ Rasio Konsistensi

$\mathrm{IR}=$ Indek Rasio

CR $<0,1$ jika nilai konsistensi melebihi $10 \%$ maka data yang diberikan oleh pengambil keputusan harus diperbaiki lagi.

\subsection{Weighted Produk Method}

[10] Menuliskan bahwa penerapan Weighted Product Method (WPM) pada sistem pendukung keputusan dapat mengatasi kesalahan dan kecurangan yang dilakukan oleh pihak tertentu serta menghasilkan keputusan yang lebih objektif. Pada WPM, solusi yang dihasilkan adalah solusi ideal yang meminimumkan kriteria biaya dan memaksimumkan kriteria keuntungan.

Langkah-langkah pada Weighted Product Method adalah sebagai berikut :

1) Merepresentasikan data awal dalam bentuk matriks $X_{\mathrm{ij}}$.

2) Menentukan kriteria keuntungan dan kriteria biaya. Sifat kriteria keuntungan adalah semakin besar nilai semakin diinginkan, sedangkan sifat kriteria biaya adalah semakin kecil nilai semakin diinginkan.

3) Menghitung nilai vektor $S$ yang merupakan nilai preferensi setiap alternatif menggunakan persamaan,

$S_{i}=\Pi_{j=1}^{m} x_{i j}{ }^{W_{j}^{*}}$

Kriteria keuntungan maka nilai pangkat adalah positif, demikian sebaliknya untuk kriteria biaya.
4) Menghitung nilai Vektor V.

$$
V_{i}=\frac{\Pi_{j=1}^{n} x_{i j}{ }^{w_{j}}}{\Pi_{j=1}^{n}\left(x_{i j}{ }^{*}\right)^{w_{j}}}
$$

Alternatif yang memiliki nilai vektor V yang terbesar merupakan alternatif yang di sarankan.

\section{HASIL DAN PEMBAHASAN}

Penelitian ini menghasilkan sistem pendukung keputusan mengunakan aplikasi Microsoft Excel. Sistem ini mengabungkan 2 buah metode yakni AHP untuk pembobotan kriteria dan WPM untuk perangkingan lokasi usaha jasa UMKM.

Terdapat 9 buah kriteria yang digunakan sehingga akan menghasilkan 81 perbandingan berpasangan. Pada AHP, langkah pertama adalah pengguna menginputkan matriks perbandingan berpasangan yang matriks segitiga atas menggunakan skala Saaty yang ditampilkan pada tabel 4.

\begin{tabular}{|c|c|c|}
\hline No. & $\begin{array}{c}\text { Nilai Variabel Linguistik } \\
\text { Kepentingan Setiap Kriteria }\end{array}$ & $\begin{array}{l}\text { Skala } \\
\text { Saaty }\end{array}$ \\
\hline 1. & $\begin{array}{lll}\text { Biaya sewa sangat } & \text { berperan } \\
\text { dibandingkan biaya renovasi } & \end{array}$ & 5 \\
\hline 2. & $\begin{array}{l}\text { Biaya sewa sangat berperan dan } \\
\text { dominan dibandingkan Ketersediaan } \\
\text { Air Bersih }\end{array}$ & 7 \\
\hline 3. & $\begin{array}{l}\text { Biaya sewa sedikit lebih berperan } \\
\text { dibandingkan Pasokan listrik }\end{array}$ & 3 \\
\hline 4. & 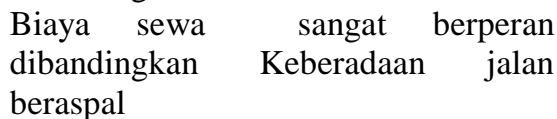 & 5 \\
\hline 5. & $\begin{array}{l}\text { Biaya sewa sedikit lebih berperan } \\
\text { dibandingkan Lahan parkir }\end{array}$ & 3 \\
\hline 6. & $\begin{array}{l}\text { Biaya sewa sangat berperan } \\
\text { dibandingkan Kepadatan penduduk }\end{array}$ & 5 \\
\hline 7. & $\begin{array}{l}\text { Biaya sewa sangat berperan } \\
\text { dibandingkan Adanya pesaing }\end{array}$ & 5 \\
\hline 8. & $\begin{array}{l}\text { Biaya sewa sangat berperan dan } \\
\text { dominan dibandingkan Kedekatan } \\
\text { dengan pemasok }\end{array}$ & 7 \\
\hline
\end{tabular}

Tabel 6. Variabel Linguistik dan Skala Saaty 
9. Biaya renovasi sedikit lebih berperan dibandingkan Ketersediaan Air Bersih

10. Biaya renovasi memiliki nilai pertimbangan berdekatan dibandingkan Pasokan listrik

11. Biaya renovasi sangat berperan dibandingkan Keberadaan jalan beraspal

12. Biaya renovasi sedikit lebih berperan dibandingkan Lahan parkir

13. Biaya renovasi sedikit lebih berperan dibandingkan Kepadatan penduduk

14. Biaya renovasi sedikit lebih berperan dibandingkan Adanya pesaing

15. Biaya renovasi sangat berperan dibandingkan Kedekatan dengan pemasok

16. Ketersediaan Air Bersih memiliki pengaruh sama besar dibandingkan Pasokan listrik

17. Ketersediaan Air Bersih sedikit lebih berperan dibandingkan Keberadaan jalan beraspal

18. Ketersediaan Air Bersih memiliki nilai pertimbangan berdekatan dibandingkan Lahan parkir

19. Ketersediaan Air Bersih memiliki pengaruh sama besar dibandingkan Kepadatan penduduk

20. Ketersediaan Air Bersih sedikit lebih berperan dibandingkan Adanya pesaing

21. Ketersediaan Air Bersih memiliki nilai pertimbangan berdekatan dibandingkan Kedekatan dengan pemasok

22. Pasokan listrik memiliki pengaruh sama besar dibandingkan Keberadaan jalan beraspal

23. Pasokan listrik sedikit lebih berperan dibandingkan Lahan parkir

24. Pasokan listrik memiliki nilai pertimbangan berdekatan dibandingkan Kepadatan penduduk

25. Pasokan listrik memiliki nilai pertimbangan berdekatan dibandingkan Adanya pesaing

26. Pasokan listrik memiliki pengaruh sama besar dibandingkan Kedekatan dengan pemasok

27. Keberadaan jalan beraspal memiliki nilai pertimbangan berdekatan dibandingkan Lahan parkir

28. Keberadaan jalan beraspal sedikit lebih berperan dibandingkan Kepadatan penduduk

29. Keberadaan jalan beraspal memiliki pengaruh sama besar dibandingkan Adanya pesaing

30. Keberadaan jalan beraspal memiliki
3

2 nilai pertimbangan berdekatan dibandingkan Kedekatan dengan pemasok

31. Lahan parkir memiliki nilai pertimbangan berdekatan dibandingkan Kepadatan penduduk

32. Lahan parkir memiliki pengaruh sama besar dibandingkan Adanya pesaing

33. Lahan parkir sedikit lebih berperan dibandingkan Kedekatan dengan pemasok

34. Kepadatan penduduk sedikit lebih 3 berperan dibandingkan Adanya pesaing

35. Kepadatan penduduk memiliki nilai pertimbangan berdekatan dibandingkan Kedekatan dengan pemasok

36. Adanya pesaing sedikit lebih berperan dibandingkan Kedekatan dengan pemasok

Variabel linguistik dikonversikan ke dalam skala Saaty untuk keperluan perhitungan. Nilai segitiga atas matriks perbandingan berpasangan berisikan perbandingan tingkat kepentingan masing-masing kriteria berdasarkan pengalaman pengambil keputusan. Nilai diagonal matriks perbandingan berpasangan bernilai 1, karena membandingkan dua elemen yang sama sehingga nilainya adalah sama penting. Nilai segitiga bawah adalah kebalikan perbandingan pada matriks segitiga atas sehingga dapat diperoleh dengan melakukan kebalikan perbandingan.

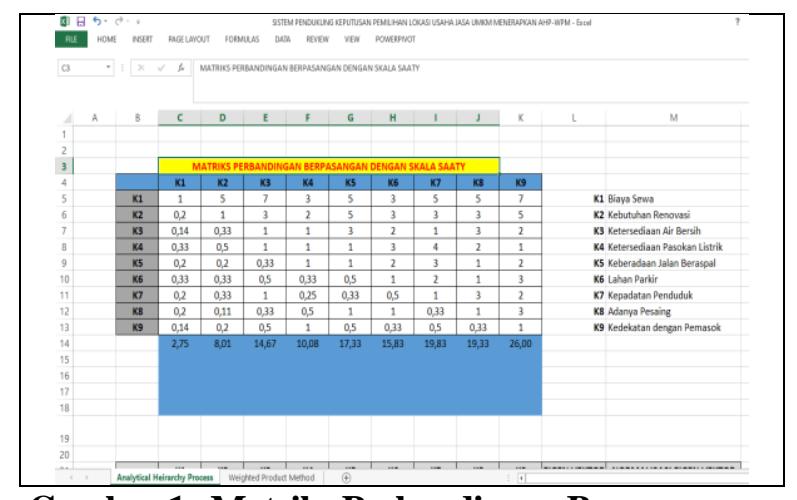

Gambar 1. Matriks Perbandingan Berpasangan 
Selanjutnya menentukan nilai eigen dengan mengalikan kolom dan baris pada matriks perbandingan berpasangan, lalu menjumlahkannya. Selanjutnya lagi melakukan normalisasi nilai eigen, caranya adalah membagi nilai eigen masing-masing kriteria dengan total keseluruhan nilai eigen semua kriteria. Normalisasi nilai eigen inilah yang akan menjadi bobot untuk masing-masing kriteria.

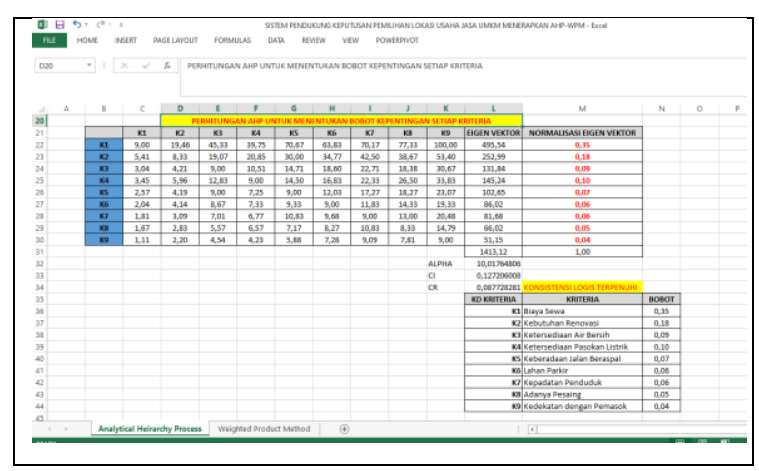

Gambar 2. Perhitungan Bobot Kriteria Menggunakan AHP

Bobot kriteria dapat digunakan apabila nilai konsistensi logis, CI $<0,1$ terpenuhi. Apabila tidak dipenuhi maka pengguna harus menginputkan lagi nilai matriks segitiga atas pada matriks perbandingan berpasangan. Berdasarkan persamaan (1) dan (2) dihitungan nilai konsistensi logis, yakni :

$$
C I=\frac{(10,018-9)}{8}=0,127
$$

Nilai IR untuk 9 kriteria adalah 1,45 (lihat tabel 5), sehingga diperoleh nilai koefesiensi logis (IR),

$$
C R=\frac{0,127}{1,45}=0,088
$$

Sehingga konsistensi logis dapat diterima dan nilai bobot kriteria dapat digunakan.

Langkah selanjutnya adalah menerapkan WPM untuk perangkingan lokasi usaha jasa UMKM. Metode WPM ini memangkatkan data kriteria untuk masing-masing lokasi usaha jasa UMKM dengan nilai bobot yang telah diperoleh pada proses perhitungan AHP. Untuk kriteria biaya (semakin kecil nilai lebih diinginkan) nilai pangkat adalah negatif, sedangkan untuk kriteria keuntungan (semakin besar nilai lebih diinginkan) nilai pangkat adalah positif. Nilai vektor $\mathrm{S}$ dihitung menggunakan persamaan (3),

$$
\begin{aligned}
L_{1}=25^{=0,35}+ & 1^{0,18}+3^{0,09}+3^{0,1}+1^{0,07} \\
& +3^{0,06}+3^{0,06}+3^{-0,05} \\
& +3^{0,04}=8,672
\end{aligned}
$$

Dan seterusnya untuk lokasi usaha jasa UMKM lainnya dilakukan dengan cara yang sama.

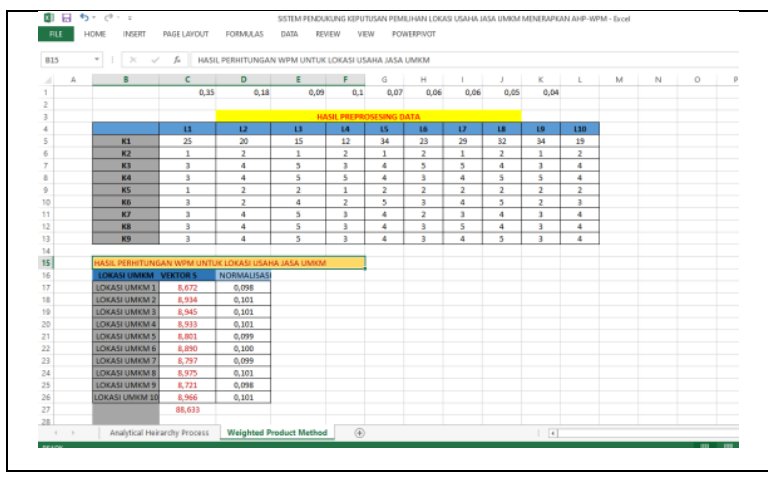

Gambar 3. Perhitungan Vektor V Lokasi Usaha Jasa UMKM menggunakan WPM

Langkah terakhir ada melakukan perangkingan berdasarkan nilai vektor V. Nilai vektor V ini adalah hasil normalisasi nilai vektor $\mathrm{S}$.

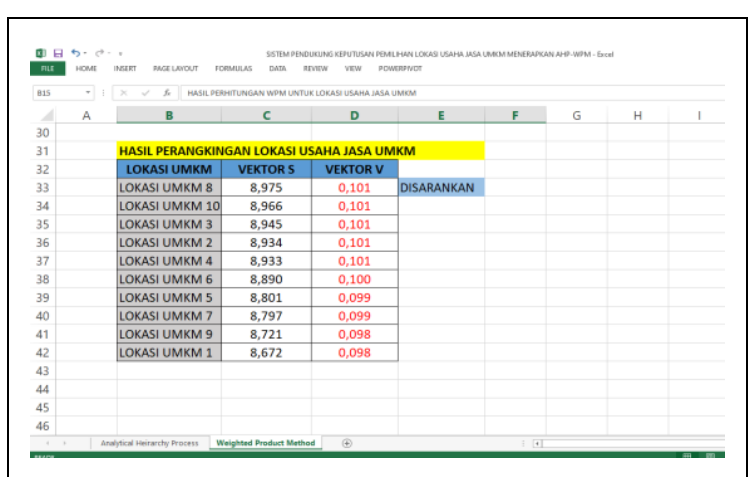

Gambar 4. Hasil Perangkingan Lokasi Usaha Jasa UMKM

Lokasi usaha yang disarankan adalah lokasi usaha ke 8 dengan nilai vektor $\mathrm{V}$ terbesar. 


\section{KESIMPULAN}

Berdasarkan pembahasan diatas dapat diambil kesimpulan sebagai berikut :

1) Pengabungan Analytical Hierarchy Process dan Weighted Product Method dapat digunakan untuk menyelesaikan masalah pemilihan lokasi usaha jasa UMKM dan menghasilkan rekomendasi lokasi yang disarankan.

2) Analytical Hierarchy Process efektif untuk menentukan bobot kriteria dengan melakukan perbandingan berpasangan untuk masing-masing-masing kriteria dan menentukan konsistensi logis untuk inputan data pengguna / pengambil keputusan.

3) Weighted Product Method efektif digunakan untuk perangkingan lokasi usaha jasa UMKM. Metode ini mencari nilai ideal dengan memaksimalkan kriteria keuntungan dan meminimalkan kriteria biaya sehingga diperoleh saran atau rekomendasi yang optimal.

\section{DAFTAR PUSTAKA}

[1] A. T. Hanggita, "Analisis Faktor Pemilihan Lokasi Usaha Jasa pada UMKM di Kecamatan Paciran," J. Manaj. Bisnis, vol. 8, no. 02, pp. 167176, 2018.

[2] E. N. Fu'ad, "Pengaruh Pemilihan Lokasi Terhadap Kesuksesan Usaha Berskala Mikro/Kecil Di Komplek Shopping Centre Jepara," Fak. Ekon. dan Bisnis, Univ. Islam Nahdlatul Ulama Jepara, vol. Vol. 30, no. 1, pp. 56-67, 2015.

[3] Diana, "Usaha Waralaba Menggunakan Metode Bayes," J. Ilm. MATRIK, vol. 19, no. 1, pp. 41-52, 2017.

[4] R. Anjasmaya and S. Andayani, "Sistem
Pendukung Keputusan Penentuan Komoditi Sayuran Berdasarkan Karakteristik Lahan Menggunakan Metode PROMETHEE," JUITA J. Inform., vol. 6, no. 2, p. 127, 2018.

[5] S. Wulandari and A. P. Wibowo, "DEVELOPMENT OF SAW ( SIMPLE ADDITIVE WEIGHTING ) METHOD FOR DECISION SUPPORT SYSTEM OF SEMBAKO PRICE CONTROL ( Case Study of the Office of Agriculture , Fisheries and Forestry, Sleman Regional Government )," Int. J. Eng. Technol. Nat. Sci., vol. 1, no. 1, pp. 1-8, 2019.

[6] R. Umar, A. Fadlil, and Y. Yuminah, "Sistem Pendukung Keputusan dengan Metode AHP untuk Penilaian Kompetensi Soft Skill Karyawan," Khazanah Inform. J. Ilmu Komput. dan Inform., vol. 4, no. 1, p. 27, 2018.

[7] P. T. Pungkasanti, "Decision Support System for Distribution of Assistance for Fishermen with Analytical HierarPungkasanti, P. T. (2019). Decision Support System for Distribution of Assistance for Fishermen with Analytical Hierarchy Process, 4(1), 2-7.chy Process," vol. 4, no. 1, pp. 2-7, 2019.

[8] R. Rahardian, N. Hidayat, and R. K. Dewi, "Sistem Pendukung Keputusan Penentuan Penerima Bantuan Keluarga Miskin Menggunakan Metode Analytical Hierarchy Process - Preference Ranking Organization for Enrichment Evaluation II ( AHP-PROMETHEE II )," J. Pengemb. Teknol. Inf. dan Ilmu Komput., vol. 2, no. 5, pp. 1980-1985, 2017.

[9] Akmaludin, "Weight Product Model ( Wpm ) for Notebook Selections Dengan Multi Kriteria Berbasis Teknologi," Pilar Nusa Mandiri, vol. XII, no. 2, pp. 111120, 2016.

[10] D. Diana and I. Seprina, "Sistem Pendukung Keputusan untuk Menentukan Penerima Bantuan Sosial Menerapkan Weighted Product Method (WPM)," J. Edukasi dan Penelit. Inform., vol. 5, no. 3, p. 370, 2019.

[11] Diana, Metode dan aplikasi sistem pendukung keputusan, 1st ed. Yogyakarta: Penerbit Deepublish, 2018. 